DP-MS-79-109

\title{
CALIFORNIUM-252 ENCAPSULATION AT THE SAVANNAH RIVER LABORATORY
}

by

A. R. Boulogne

E. I. du Pont de Nemours \& Co. Savannah River Laboratory

Aiken, SC 29808

A paper to be presented at the Second Chemical Congress of the North American Continent Symposium to be held in San Francisco, CA on August $24-29,1980$.
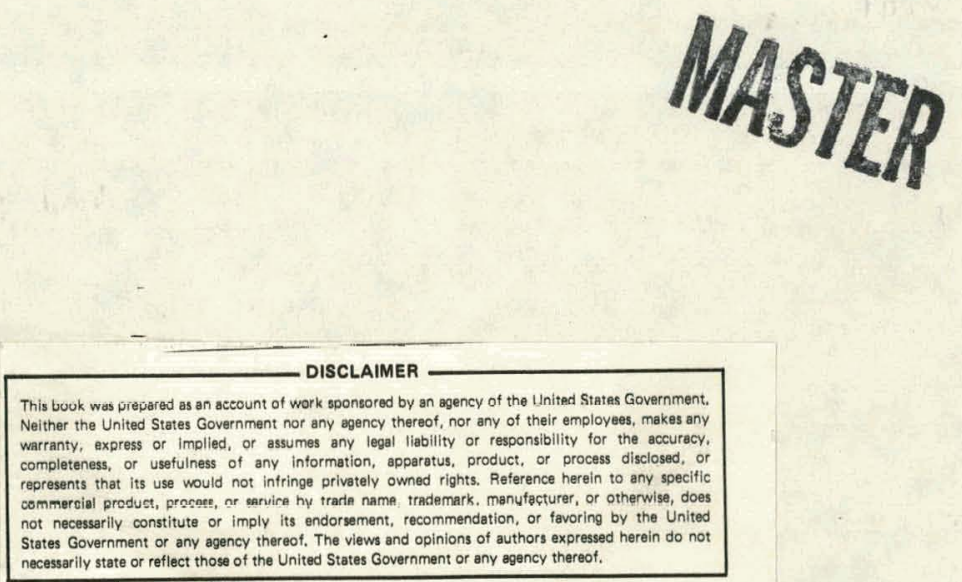

This paper was prepared in connection with work under Contract No. DE-AC09-76SR00001 with the U. S. Department of Energy. By acceptance of this paper, the publisher and/or recipient acknowledges the U. S. Government's right to retain a nonexclusive, royalty-free license in and to any copyright covering this paper, along with the right to reproduce and to authorize others to reproduce all or part of the copyrighted paper. 


\section{DISCLAIMER}

This report was prepared as an account of work sponsored by an agency of the United States Government. Neither the United States Government nor any agency Thereof, nor any of their employees, makes any warranty, express or implied, or assumes any legal liability or responsibility for the accuracy, completeness, or usefulness of any information, apparatus, product, or process disclosed, or represents that its use would not infringe privately owned rights. Reference herein to any specific commercial product, process, or service by trade name, trademark, manufacturer, or otherwise does not necessarily constitute or imply its endorsement, recommendation, or favoring by the United States Government or any agency thereof. The views and opinions of authors expressed herein do not necessarily state or reflect those of the United States Government or any agency thereof. 


\section{DISCLAIMER}

Portions of this document may be illegible in electronic image products. Images are produced from the best available original document. 


\title{
CALIFORNIUM-252 ENCAPSULATION AT THE SAVANNAB RIVER LABORATORY*
}

by

\author{
A. R. Boulogne \\ E. I. du Pont de Nemours \& Co. \\ Savannah River Laboratory \\ Aiken, SC 29808
}

Introduction

More than $1 \mathrm{~g}$ of the neutron-emitting isotope californium-252 has been encapsulated at the Savannah River Laboratory (SRL) for worldwide medical, industrial, and research uses. Bulk sales packages have been prepared for the U. S. Department of Energy (USDOE) sales program since 1971. Doubly-encapsulated sources have been prepared for USDUE's market evaluation progran since 1968. Californium-252 sources for loan and sales packages satisfy the criteria for Special Form Radioactive Material (1). Encapsulation is performed in special neutron-shielded containment facilities at SRL $(\underline{2}, \underline{3})$. Development. of improved source and shipping package designs and procesacs ic a continuing effort.

* The information contained in this article was developed during the course of work under Contract No. DE-AC09-76SR0000l with the U. S. Department of Energy. 


\section{Source Forms}

Californium-252 is encapsulated and shipped in eight standard Special form capsules and packages. The isotope is available as californium oxide, californium-palladium cermet wire or pellets, and, in the case of medical therapy sources, californium-palladium cermet sheathed in platinum-iridium alloy. Capsules are available in a variety of metals and alloys (Table 1, Figures 1 through 8 ).

\section{Capsule Integrity}

The integrity of the design and construction of each source and sales package was demonstrated by subjecting active sources to tests simulating expected adverse service conditions as specified in "Tests for Special Form Materials" (1). These tests include:

- Impact (falls $10 \mathrm{~m}$ on unyielding surface)

- Percussion (1.4-kg weight, 25-mm diameter, falls $1 \mathrm{~m}$ )

- Heating ( 10 minutes at $800^{\circ} \mathrm{C}$ )

- Immersion (24 hours in water at room temperature)

Special tests not specified by U. S. regulatory agencies were cunlucted to simulate expected service r.nnditions. Dummy secondary capsules of the $S R-C f-100$ series were subjected to internal and external pressures far in excess of pressures expected under the most adverse industrial service conditions. The special tests 
that successfully demonstrated the integrity of source construction and the seal welds were:

- Burst tests of the circumferential welds

- Crush tests

- Hydrostatic compression tests

Similarily, special tests to demonstrate the integrity of the californium-252 seed assemblies (ALC-P4C) under conditions that might conceivably be expected during medical service were:

- Sterilization

- Pinching

- Crushing

- Bending

In addition to all of the above tests, quality assurance tests during encapsulation demonstrate the integrity of each californium-252 sales package and neutron source.

Quality Assurance

Californium Assay and Analyses.

Quality control for the californium feedstock is accomplished by measuring the neutron emission rate of an aliquot of the starting material and by performing analyses for isotopic content and chemical purity. Neutron emission rate is measured in a fission counter (4). Isotopic content is measured by mass spectrometry and chemical purity by spark source mass spectrometry. The completed assembly is leak tested, decontaminated, and assayed before packaging and shipping. 
Inspecting Capsule Components.

Prior to cleaning, capsule components are inspected for

dimensional accuracy and machining flaws.

Cleaning Capsule Components Prior to Use.

Metal components are thoroughly degreased and cleaned to

remove cutting oil, grease, fingerprints, and dirt.

Welding Control.

Plugs in the inner and outer capsules for the sales packages and industrial sources are seal-welded with an argon-shielded or helium-shielded tungsten electrode DC arc. The capsule is rotated under the automatically controlled arc to produce a minimum weld penetration of $1.27 \mathrm{~mm}$. Each weld bead is visually inspected by periscope or by Questar* telescope, and imperfectly formed welds are rejected. Weld quality is controlled by periodic metallographic examination of dummy capsules welded in the in-cell equipment.

Capsule closures for medical sources and seeds are made with an argon-shielded plasma DC arc. The arc is controlled to produce a wcld bog̣d penetration equal to, or greater than, the capsule wall thickness. Each weld bead is visually inspected by a $20 \mathrm{X}$ stereoscopic microscope or by Questar telescope. Weld quality is controlled in the same manner as with sales packages and -.. industrial sources.

* Trademark of Questar Corporation 


\section{Leak Testing.}

Sealed capsules of sales packages and industrial sources are pressurized in 300 psi helium for 20 minutes. Leak tests are performed on individual capsules in a helium leak detector whose lower limit of detection is $1.0 \times 10^{-8}$ standard cubic centimeters of helium per second. All capsules must show no detectable leak.

Leaks in medical sources and seeds are detected by a vacuum immersion leach test. Because the internal volume of the medical sources is so small $\left(3.6 \times 10^{-4} \mathrm{cc}\right.$, in case of the ALC-P4C seed), the conventional helium leak test is not a valid leak test procedure. About 45 minutes is required to pump down the system before helium measurement is begun. If the internal volume of the test specimen is small, trapped helium would: escape before helium assay begins. Therefore, leaks in encapsulated medical sources are detected by measuring the alpha activity of a nitric acid penetrant solution in which the source had been immersed. After immersion, pressure above the liquid is decreased to 2.5 psia for 3 minutes before venc1ng to alwuspliere. This proccdure ic repeated twice, then the sources remain in acid a minimum of 16 hours at $^{-}$ $20^{\circ} \mathrm{C}$. A $1-\mathrm{mL}$ sample of the leach solution is assayed for alpha radioactivity, and the sources are rejected if the alpha count exceeds $10 \mathrm{~d} / \mathrm{m}$ above background. 


\section{Labeling.}

Sales packages are identified by engraved designations which are numbered serially ( $S R-C f-1001, S R-C F-1002$, etc.). Industrial sources are also numbered serially in the -100 series ( $S R-C f-101$, SR-Cf-102, etc.). Each package and source is provided with an information sheet listing pertinent construction, test, and calibration data.

Medical sources and seeds are not identified by engraving so as not to lessen the integrity of the $0.015 \mathrm{~mm}$ wall. Successive groups of sources made for each contractor are identified by uniquely positioned gold bands, or other color coding as requested by the user to accommodate handling procedures. Information sheets are furnished as with sales packages and industrial sources.

\section{Facilities}

Sales Packages and Industrial Sources.

All industrial encapsulations and the preparation of cermet pellets for medical sources are performed in a facility that limits radlaliui exposure rates to lces than 1 mrem/hr in normally occupied areas. Maximum amounts of up to $100 \mathrm{mg}$ of californium-252 may be handled in this shielded facility. Figures 9 and 10 show the cell complex, which is surrounded by a maximum of $1.22 \mathrm{~m}$ of gamma and neutron shielding. Because the chemical and encapsulation procedures require microtechniques, in-cell equipment has been designed for remote handling, assembly, and examination of microliter quantities of solutions and capsule components ranging in 
size from $0.317 \mathrm{~cm}$ long cylinders (porous disks) to $15.74-\mathrm{cm}-10 \mathrm{ng}$ outer capsules (sales packages). This remotely operated equipment includes an ion column leaching apparatus, an automatic pipettor, special dies and fixtures for hydraulic presses, a programable tungsten arc, inert-gas shielded welder, an ultrasonic decontamination system, electronic assay systems (fission counters and $\mathrm{BF}^{3}$ counters), and a portable in-cell fast neutron monitor. Small samples can be transferred from three of the five operating positions to an adjacent laboratory by a pneumatic transfer system.

\section{Medical Sources.}

All medical encapsulations are done in a facility which consists of a series of five interconnected stainless steel boxes which provide primary containment of process equipment and materials. Interconnections include transfer ports, drop-through tubes, and ventilation ducts. Each containment enclosure has a floor area of $1.52 \mathrm{~m} \times 0.91 \mathrm{~m}$; the floor level is $0.76 \mathrm{~m}$ above the building floor. A pair of master-slave manipulators serve each containment box. A closed circuit television system and a telescope are provided for close-up viewing of in-cell operations andcan be moved from cell to cell as needed. General arrangement of the facility is shown in Figures 11 and 12.

Two glove boxes at the rear of the facility are for material entry and exit operations. Two additional glove boxes provide containment for the access tubes that are used for removal of swipes used to assess effectiveness of decontamination procedures. 
The containment cells are shielded on the front, back, ends, and top by concrete blocks. There is no shielding between containment enclosures. Wall thickness of the blocks is approximately $0.99 \mathrm{~m}$. Shield windows are installed in the front face of the containment enclosures. The inner plate is $2.54 \mathrm{~cm}$ radiation stabilized glass; the outer plate is $2.29 \mathrm{~cm}$ Pyrex* borosilicate glass. Space between these plates is filled with 0.91 m water, which circulates continuously through a filtration-clarification system. Manipulators are mounted in concrete-filled lintels. Concrete blocks, totaling $0.77 \mathrm{~m}$ thickness, shield the top of the facility.

Normal production requires Containment Boxes 1 and 2 to contain approximately $400 \mu \mathrm{g}$ of californium-252 as californium-palladium cermet.- While operating in this mode, general area dose rates are about $1 \mathrm{mrem} / \mathrm{hr}$ where personnel usually operate in front of the boxes. Dose rates behind the cells in normally unoccupied areas range $^{-}$from 4 to $6 \mathrm{mrem} / \mathrm{hr}(\underline{3}):$

Medical sources are fabricated with remotely operated, specially designed machines (5). The fabrication process involves production of a platinum - 10\% iridium-clad wire with a californium oxide-palladium cermet core. The wire is swaged and drawn to size, cut to length, and welded in a Pt - 10\% Ir capsule. Nominally,

\footnotetext{
* Trademark - Corning Glass Works, Corning, N.Y.
} 
medical sources contain from $0.3 \mu \mathrm{g}$ californium-252 in an individual seed (Figure 8 ) to $30^{\circ} \mathrm{\mu g}$ californium-252 in an applicator tube (Figure 7).

Feed to the medical source facility is a composite billet prepared in the sales and industrial source packaging facility. The billet contains a californium oxide-palladium core gold-brazed in a Pt - $10 \%$ Ir container $(0.76-\mathrm{cm}$ diameter $\mathrm{x} 3.56 \mathrm{~cm} 10 \mathrm{ng})$. The core is prepared by deposition of palladium on a fine precipitate of californium-252 oxalate in an aqueous system (6).

The clad wire is made by swaging and drawing. This wire provides a source form that can be subdivided with a minimum of contamination. The swaging operation requires five reductions and one anneal at $1100^{\circ} \mathrm{C}$ to reduce the billet from $7.6 \mathrm{~mm}$ to $2.5 \mathrm{~mm}$ in diameter. The drawing operation requires approximately 44 passes, which reduces the cross-sectional area of the wire by $10 \%$ per draw. Four annealing cycles at $1100^{\circ} \mathrm{C}$ are required during the drawing operation. These operations produce a finished wire with a reasonably symmetrical cross-section (5). The swager-draw bench, a precisision.cutter, toading and welding equipment, and the leak testing apparatus were designed specifically for this process.

Development

Brachytherapy Sources.

The first californium-252 sources for radiotherapy research were prepared at SRL about fourteen years ago $(\underline{7}, \underline{8})$. Initially, these sources resembled the classical radium needles familiar in 
clinical radiotherapy. Eventually, afterloading cells and applicator tubes were supplied to medical evaluators, and all medical sources were improved by the use of californium-palladium cermet wire sheathed in Pt - $10 \%$ Ir alloy $(\underline{6}, \underline{9})$. The most recent designs for medical sources produced in quantity for therapy research are line sources and point sources containing a range of californium-252 from less than $1 \mu \mathrm{g}$ to $200 \mu \mathrm{g}$ (Figures 13 and 14 ).

The purpose of the development work described in this paper is to prepare physically small, yet intense californium-252 sources for remote afterloading brachytherapy research. Remote afterload.... ing is used by many hospitals to avoid radiation exposure to medical and hospital personnel.

At least five designs of remote afterloaders are available: the "Curietron" in France, the "Cervitron-II" in Switzerland, the "Cathetron" in England, the "Hicesitron" in the United States, and the "Brachytron" in Canada. The afterloading sources described in this paper were designed specifically for the "Brachytron" manufactured by AECl, Canada, and for a remote afterloader manufactured by Toshibä Electric Co. Ltd., Japan.

Typically, a remote afterloader is a shielded cell or treatment room. Long cables pass through the wall of the room from an operating station outside the room to a patient treatment position inside the room. Radioactive sources are attached to the cables at the patient treatment position. With the patient in the treatment room and the shielded room door closed, the sources are advanced to 
the treatment position in previously installed applicators by means of the cables and a mechanism in the control system outside the treatment room wall. Our goal was to adapt sources containing up to $200 \mu \mathrm{g}$ of californium-252 to use in these remote afterloaders. Hardware for the "Brachytron" was designed for use with cobalt-60 sources; straight or curved catheters are available. The "stiff" length of the source is defined by the minimum radius through which the source must travel. Available catheters will accept sources whose "stiff" length is between $15.2 \mathrm{~mm}$ and $24.4 \mathrm{~mm}$. We have prepared $200 \mu \mathrm{g}$ californium-252 sources with the shortest possible. "stiff" length and the greatest possible integrity. These sources were prepared by a modified chemical plating, technique similar to that used to prepare palladium-californium oxide cermet for industrial applications ( 6 ). Design of the doubly encapsulated source with its protective sheath is shown in Figure 13. Length of the source with its sheath is $13.8 \mathrm{~mm}$. Outside diameter of the source, including its sheath, ${ }^{-}$is $2.8 \mathrm{~mm}$. Existing "Brachytrons" can accommodate this source form. This capsule system will withstand internal gas pressure from helium due to alpha decay and fission gases from a $200 \mu \mathrm{g}$ source after ten years if the source is subjected to a maximum temperature of $800^{\circ} \mathrm{C}$ (the assumed temperature of an accidental fire). Under these $\cdots$ conditions, the safety factor is 9. 
Neutron sources for the Toshiba Electric Co. afterloader can be slightly larger in physical size than "Brachytron" sources and must also contain approximately $200 \mu \mathrm{g}$ of californium-252. The source carrier will accept a doubly encapsulated source $9.8 \mathrm{~mm}$ long x $4.7 \mathrm{~mm}$ diameter (Figure 14). The two capsules are made of Pt $10 \%$ Ir alloy and are seal-welded with an argon-shielded tungsten electrode DC arc. We have prepared eight of these sources containing nanogram amounts of californium-252 and have subjected them to tests specified for Special Form Materials ( 1 ) and to other adverse service conditions that include sterilization, pinching, crushing, and abrasion. The sources successfully passed all safety tests. Using the same process, we prepared and shipped three nominal $200 \mu \mathrm{g}$ californium-252 sources to the Keio University School of Medicine in Tokyo, Japan for evaluation in the ToshibalElectric Co., Ltd. afterloader. Three additional sources are currently being fabricated for the same evaluator.

\section{Storage and Shipping}

Although special containment and shielding considerations apply to californium-252 handling, the problems of radiation protection are straightforward (10). Sources containing more than a few micrograms of californium-252 must be handled remotely and stored in hydrogenous shields rather than high density materials, such as lead. 
During the past fourteen years, special equipment, procedures, and carriers have been developed for safe, practical handing, storage, and shipment of encapsulated californium-252 sources. Tools and fixtures were designed to attach magnetic eyelets for remote transfer of finished sources. Sources are stored in large polyethylene tanks filled with a cast matrix of water-extended polyester (WEP)(11). Boric acid for neutron absorption and ethylene glycol for freeze protection are incorporated in the aqueous phase. Figure 15 is a photograph of a 500-gallon polyethylene tank filled with WEP. The central storage well is a $10.16-\mathrm{cm}$ pipe surrounded by $5.08 \mathrm{~cm}$ of lead for primary gamma shielding. The radiation dose rate at 3 feet from this container with 8 sources totaling $34.6 \mathrm{mg}$ californium-252 in the center well was 55 $\mathrm{mrem} / \mathrm{hr}(42 \mathrm{mR} / \mathrm{hr}$ gamma $+13 \mathrm{mrem} / \mathrm{hr}$ neutron radiation).

Fourteen years ago, a few shipping casks. with sufficient shielding to accommodate $200 \mu g$ of californium-252 were available; however, none existed for handling milligram quantities. Since that time, shipping casks have been constructed at U. S. Department of Energy "sitës for transporting Type A and Type $\bar{B}$ quantities of californium-252 and at commercial cask fabricators for transporting Type A quantities (12). These casks satisfy Department of Energy, Nurlear Regulatory Commission, and Department of Transportation sperifications. 
Type A packaging means packaging which is designed in accordance with the general packaging requirements and is adequate to prevent the loss or dispersal of the radioactive contents and to retain the efficiency of its radiation shielding properties if the package is subject to normal transportation.

Type B packaging means packaging which meets the standards for Type A packaging, and, in addition, meets the standards for hypothetical accident conditions for transportation (1).

Maximum quantity of californium-252 in Special Form packaging permitted for Type A shipment is $2.0 \mathrm{Ci}(3.73 \mathrm{mg})$. Figure 16 shows a typical Type A cask permitted for shipment of $2.0 \mathrm{Ci}$ californium252 in a Special Form package. This SRL californium-252 Transfer Cask uses Benelex 401* for shielding, is $1.22 \mathrm{~m}$ wide $\times 1.32 \mathrm{~m}$ high, octagonal in shape, and weighs $2386 \mathrm{~kg}$.

Figure $17^{\circ}$ shows the SRL 4.5-ton Californium Shipping Cask for shipment of Type B quantities in Special Form packaging (13). This cask is identified as USA/6642/B. It has USNRC Certificate of Complịance 6642 and International Atomic Energy Agency (IAEA) Certifirate of Competent Authority USDOT USA/6642/B. The cask is a $1.52 \mathrm{~m}$ diameter steel sphere filled with WEP as the neutron shield. It weighs $4332 \mathrm{~kg}$ and can carry $46 \mathrm{Ci}$ ( $85 \mathrm{mg}$ ) californium-252 in Special Form packaging.

* Trademark of the Maconite Corporation 


\section{LITERATURE CITED}

1. Code of Federal Regulations, "Transportation", Title 49, Paragraph 173.398, April 23, 1976.

2. Boulogne, A. R. "Californium-252 Encapsulation and Shipping at SRL," USERDA Report CONF-720902, Applications of Californium-252, ANS National Topical Meeting, Austin; TX, September 11-13, 1972 , $(1975), 36$.

3. Moyer, R. A. Safety Analysis of the Californium Medical Source Facility, USAEC Report DPSTSA-700-11, E. I. du Pont de Nemours \& Co., Savannah. River Laboratory, Aiken, SC, 19.73 .

4. Herold, T. R. "Electronic Assay of ${ }^{252} \mathrm{Cf}$ Neutron Sources." Nuclear. Technology, $14,1972,269-278$.

5. Permar, P. H., Walker, V. W.,."Californium-252 Radiotherapy Sources for Interstitial Afterloading," USAEC Report CONF-760436, Proceedings of the Paris Symposium of the International Symposium on Californium-252 Utilization, Paris, France, April 26-28; 1976, Volume II, Session II, 145-159.

6. Mosley, W. C., Smith, P. K., McBeath, P. E. "Neutron Sources of Palladium-Californium-252 Oxide Cermet Wire," USERDA Report CONF-720902, Proceedings of the American Nuclear Society Topical Meeting, September 11-13, 1972, (1975), 51-60.

7. Boulogne, A. R., Evans, A. G. "Californium-252 Neutron Sources for Medical Applications," Int. J. Appl. Rad. Isu., 20, 1969, 453. 
8. Wright, C. N., Boulogne, A. R., Reinig, W. C., Evans, A. G. "Implantable Californium-252 Neutron Sources for Radiotherapy," Radiology, 89, 2, 1967, 337 .

9. Walker, V. W. "Equipment and Operations for Preparing Neutron Sources for Interstitial Cancer Radiotherapy Research," Trans. Am. Nucl. Soc. $22,1975,730$.

10. Wright, C. N. "Radiation Protection for Safe Handling of Californium-252 Sources," Health Physics, 15, 1968, 446.

11. Oliver, Jr., G. D., Moore, E. B. "Neutron Shielding Qualities of Water-Extended Polyesters." Health Physics, 19, 1970, 578.

12. Californium-252 Progress, Numbers 1 through 22, Savannah River Operations Office, U. S. Department of Energy, Aiken, SC, 1970-1978.

13. Whatley, V., Jr., Mahoney, D. J., Livingston, J. T. Safety Analysis Report - Packages, SRL 4.5-Ton Californium Shipping Cask, USAEC Report DPSPU-74-124-6, Rev. 1, E. I. du Pont de Nemours \& Co., Savannah River Laboratory, Aiken, SC, March, 197.6 
TABLE 1

Standard Source Forms

Model

$S R-C f-X X$

$S R-C F-1 X$

$S R-C f-100$

4

ALC - X

SALC $-\mathrm{X}$

6

$\mathrm{AT}-\mathrm{X}$

7

SEEDS

$(\Lambda \mathrm{LC}-\mathrm{P} \wedge \mathrm{C})$

1

2

3

5
Figure

Radiotherapy after-

loading cell for

interstitial implan-

tation

Short afterloading

cell for interstitial

implantation

Radiotherapy applicator tube for intracavitary

implantation

Radiotherapy seed

assemblies for

interstitial

implantation
Use

For loan in the market evaluation program

For loan in the market evaluation program

For loan in the market evaluation program

For all shipments of ${ }^{252}$ Cf purchased by encapsulators and users (may be in the form of oxide, cermet wire, or cermet pellets)

For loan in the market evaluation program

For loan in the medical evaluation program

For loan in the medical evaluation program

For loan in the medical evaluation program 


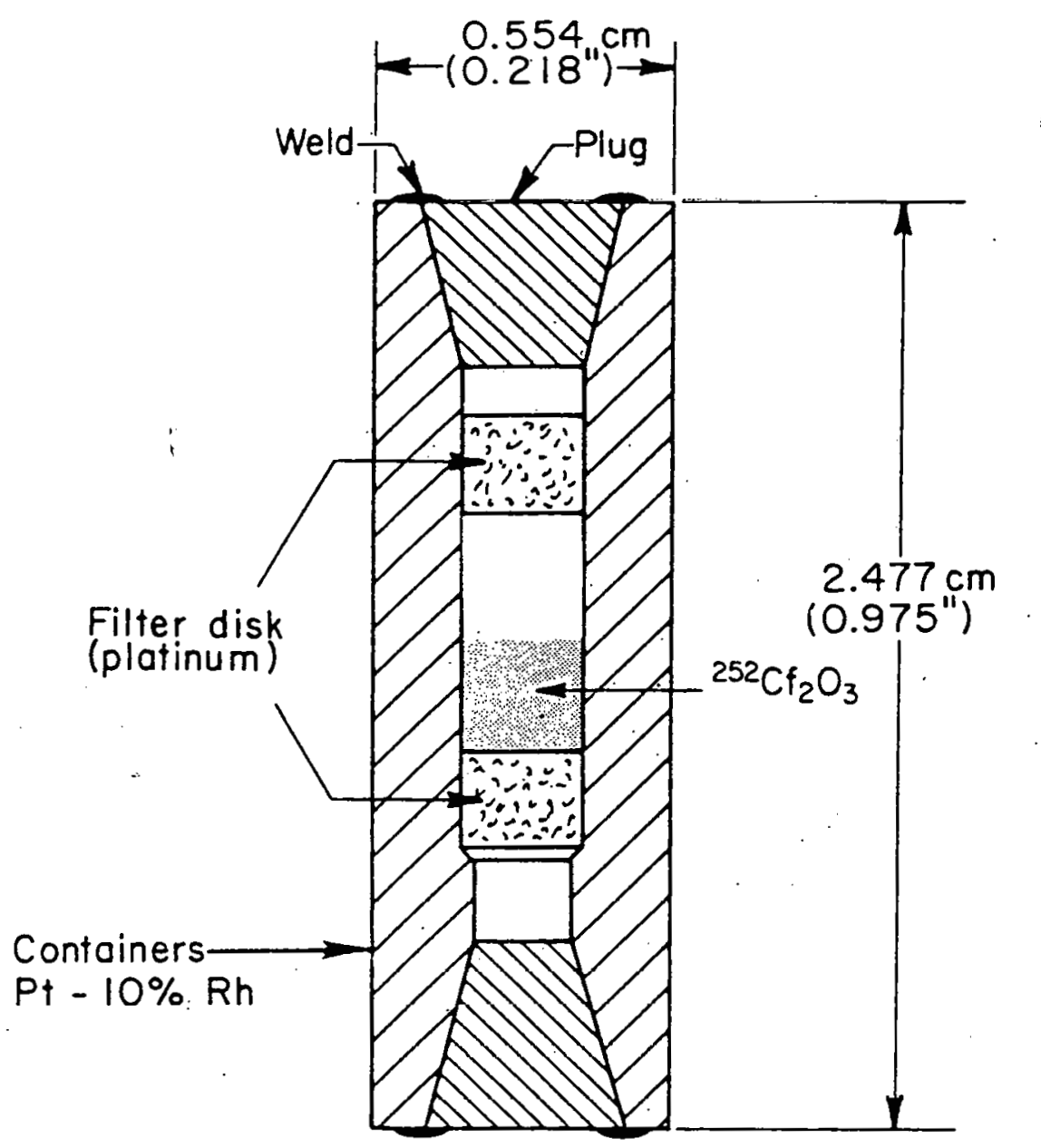

Fig. 1 Primary capsule for "point" sources of ${ }^{252} \mathrm{Cf}$ oxide (SR-Cf-XX) 


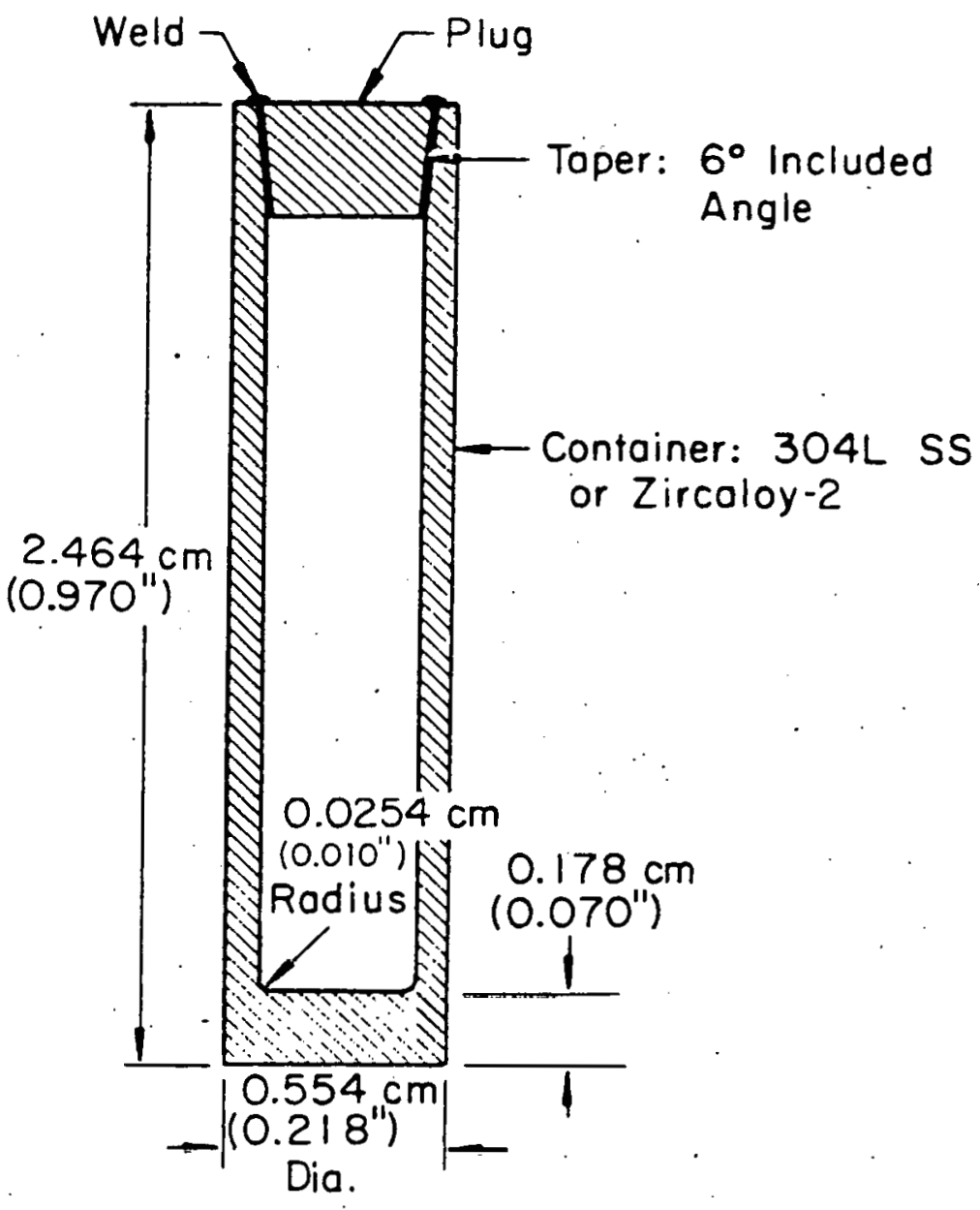

Fig. 2 Primary capsule for "line" sources of ${ }^{252}$ Cf cermet wire or "point" sources of cermet pellets (SR-Cf-1X) 


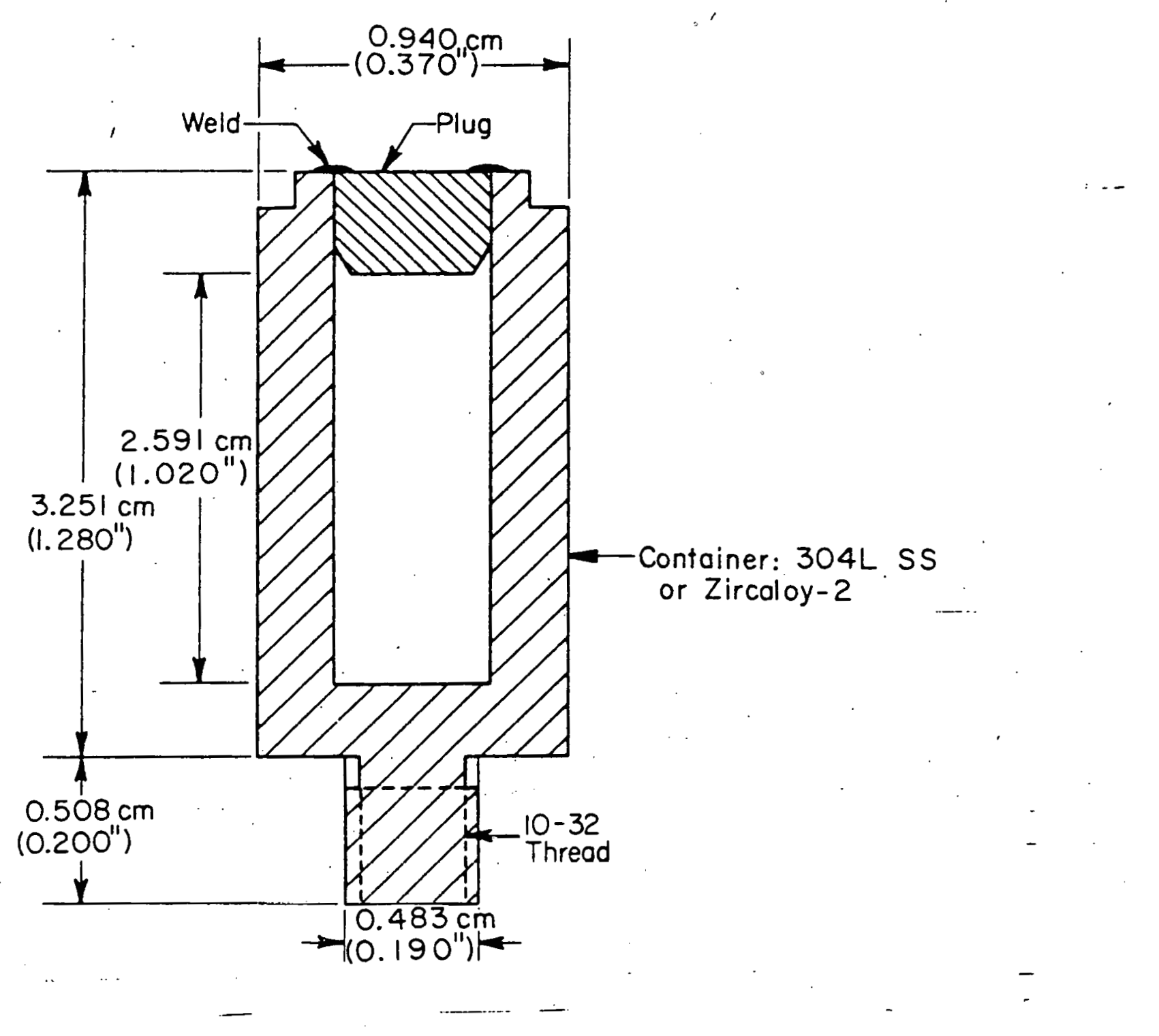

Fig. 3 Secondary capsule (may contain either SR-CF-IX or SR-Cf-XX primary capsule) '... (SR-Cf-100) 


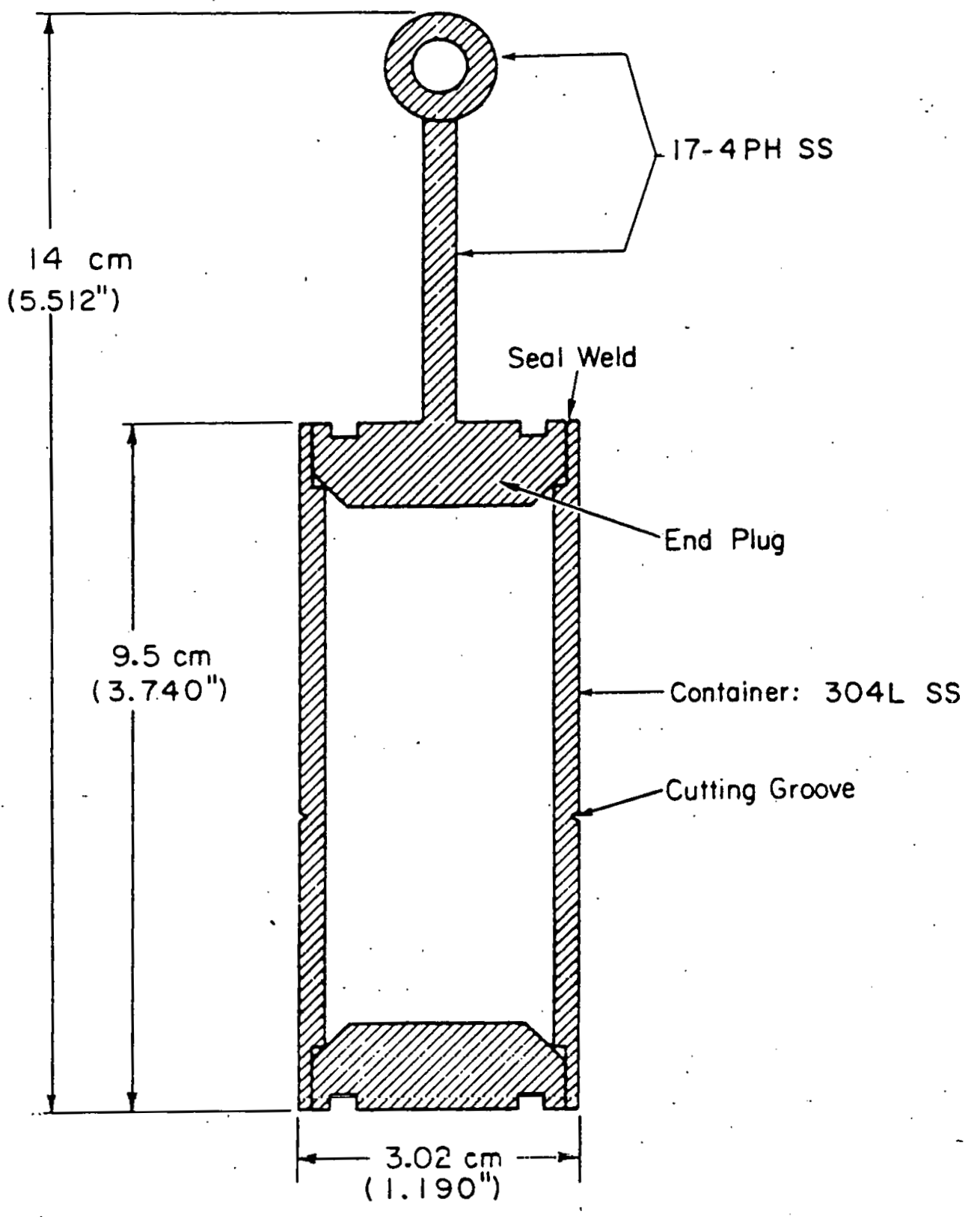

Fig. $4 \quad 252 \mathrm{Cf}$ shipping capsule assembly (SR-CF-1000) 


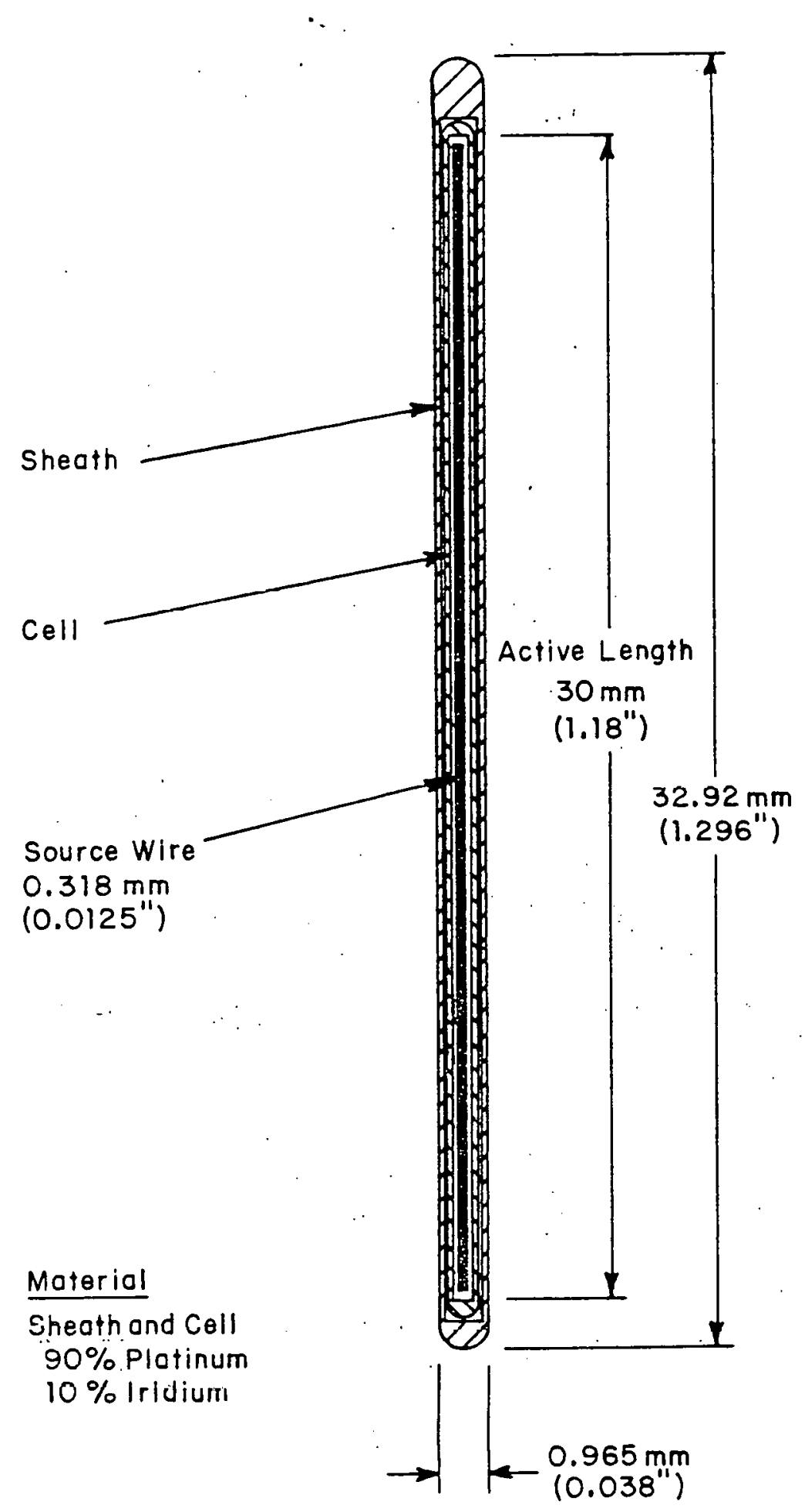

Fig. 5 Radiotherapy afterloading cell for interstitial implantation (ALC-X) 


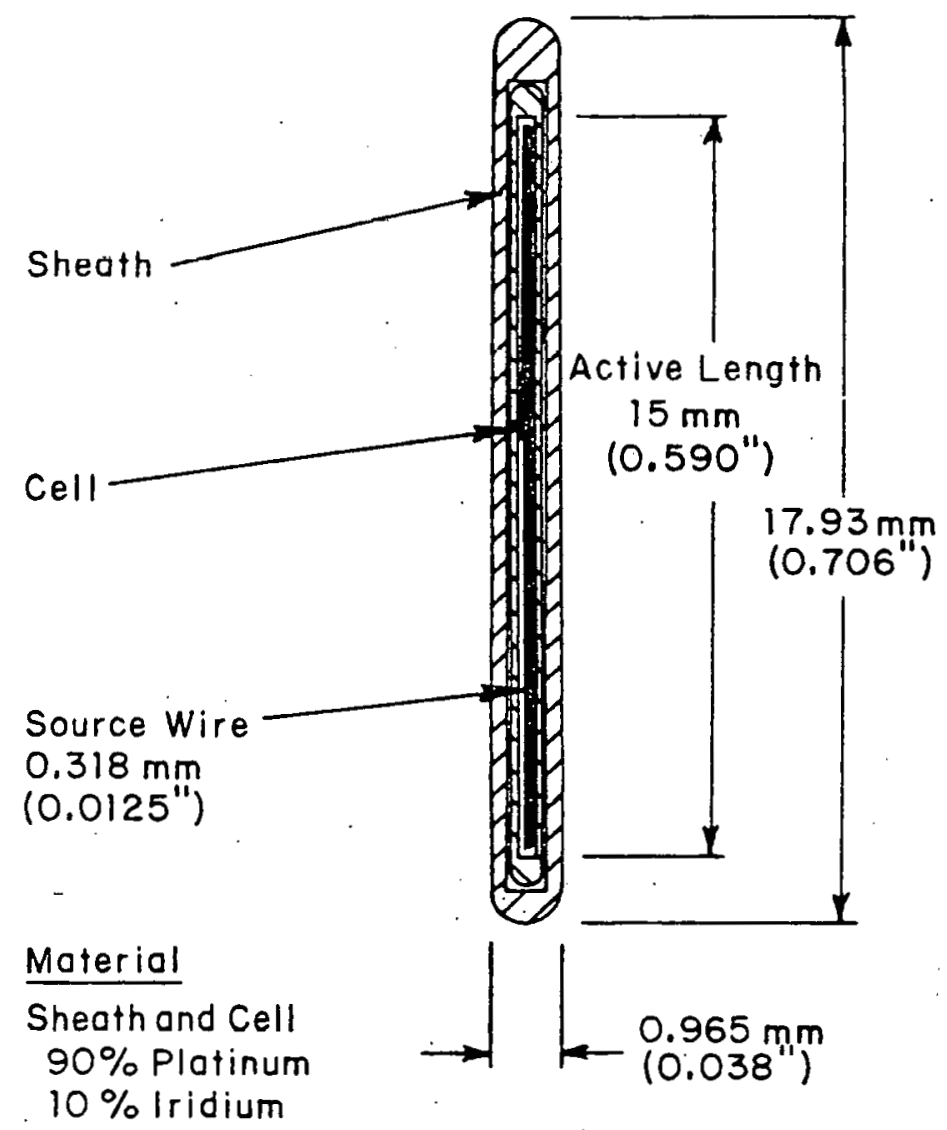

Fig. 6 Short afterloading cell for interstitial implantation (SALC-X) 


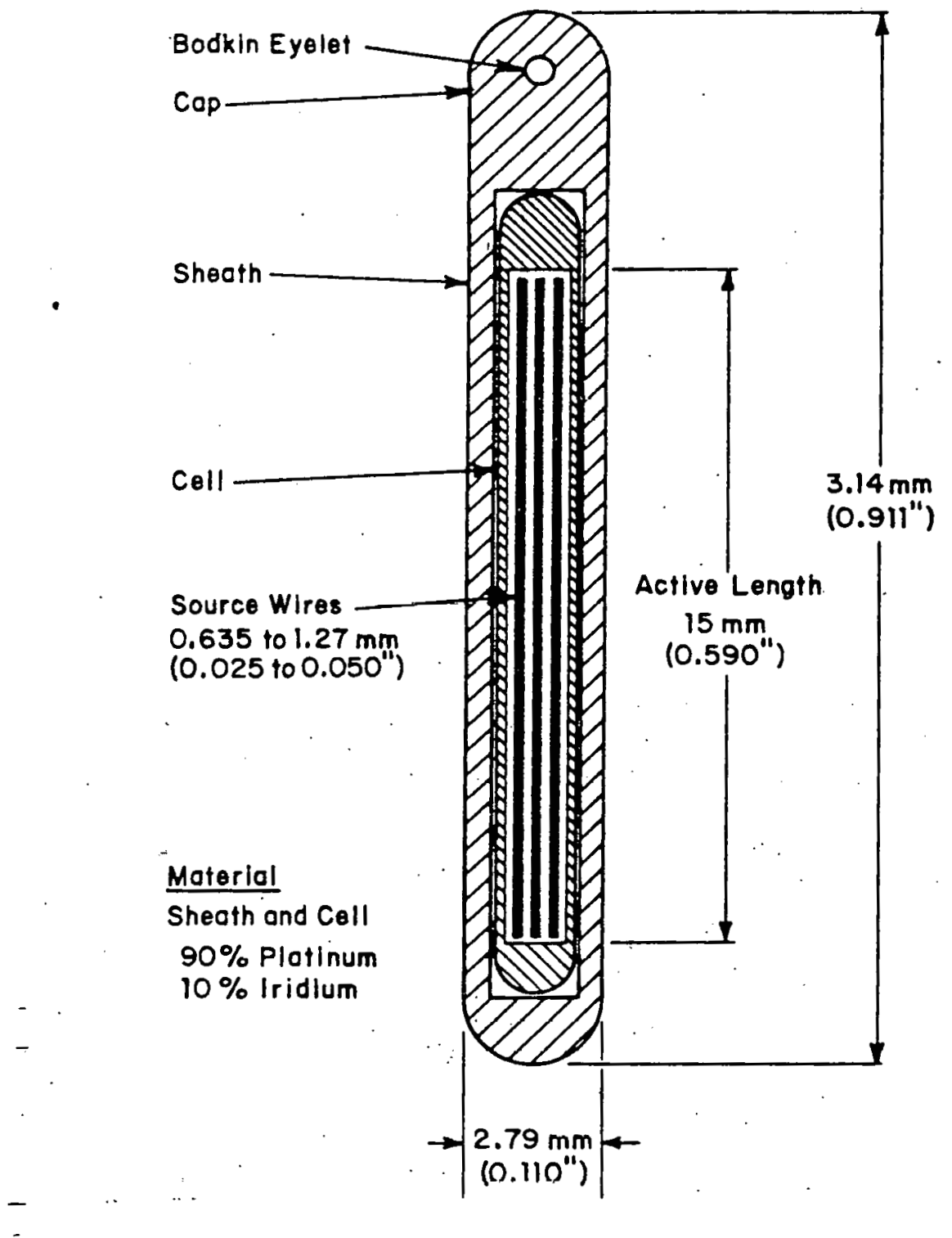

Fig. 7 Radiotherapy applicator tube for intracavitary implantation (AT-X) 

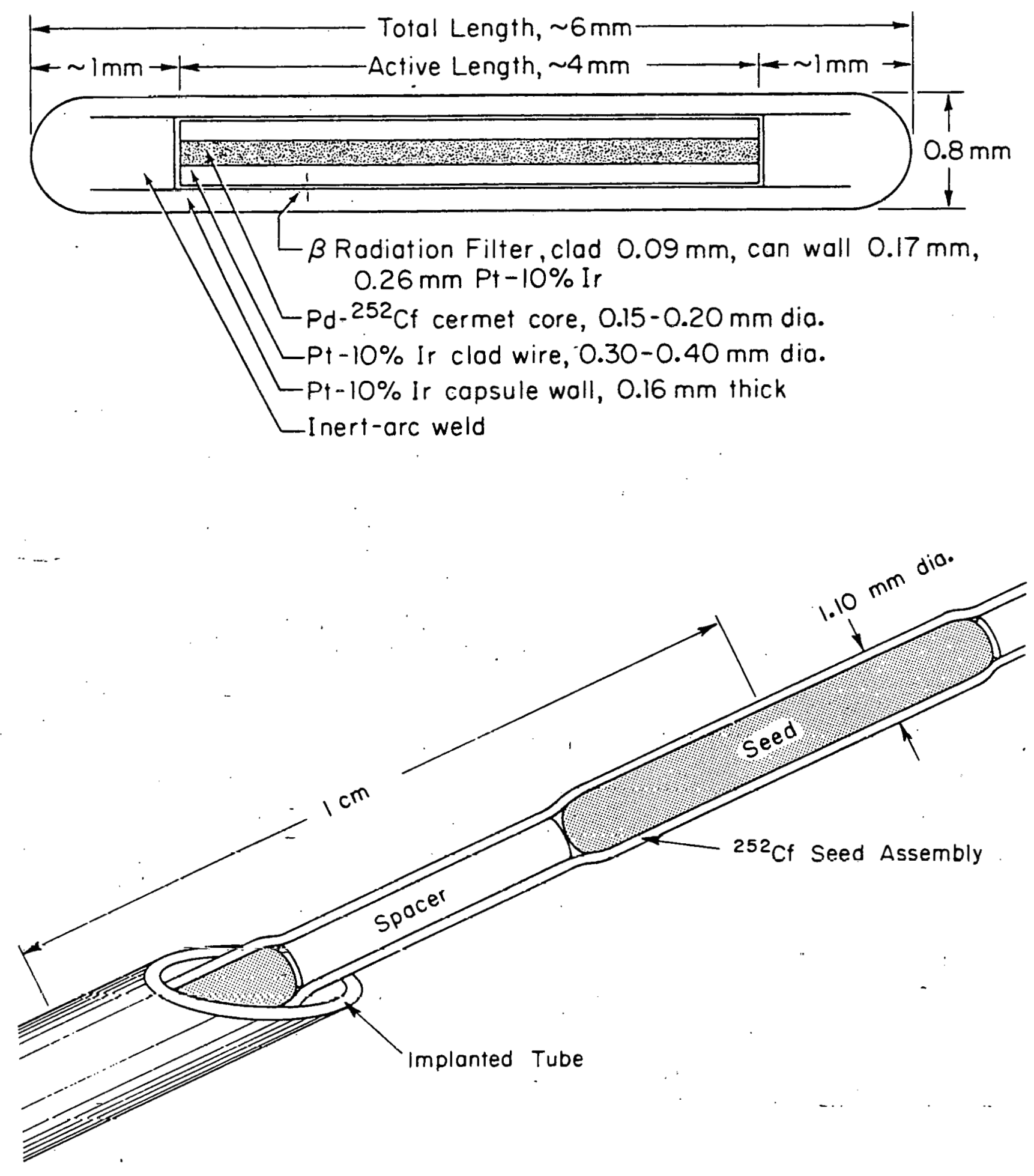

Fig. 8 Radiotherapy seed assemblies for interstitial implantation (Seeds) (ALC-P4C) 


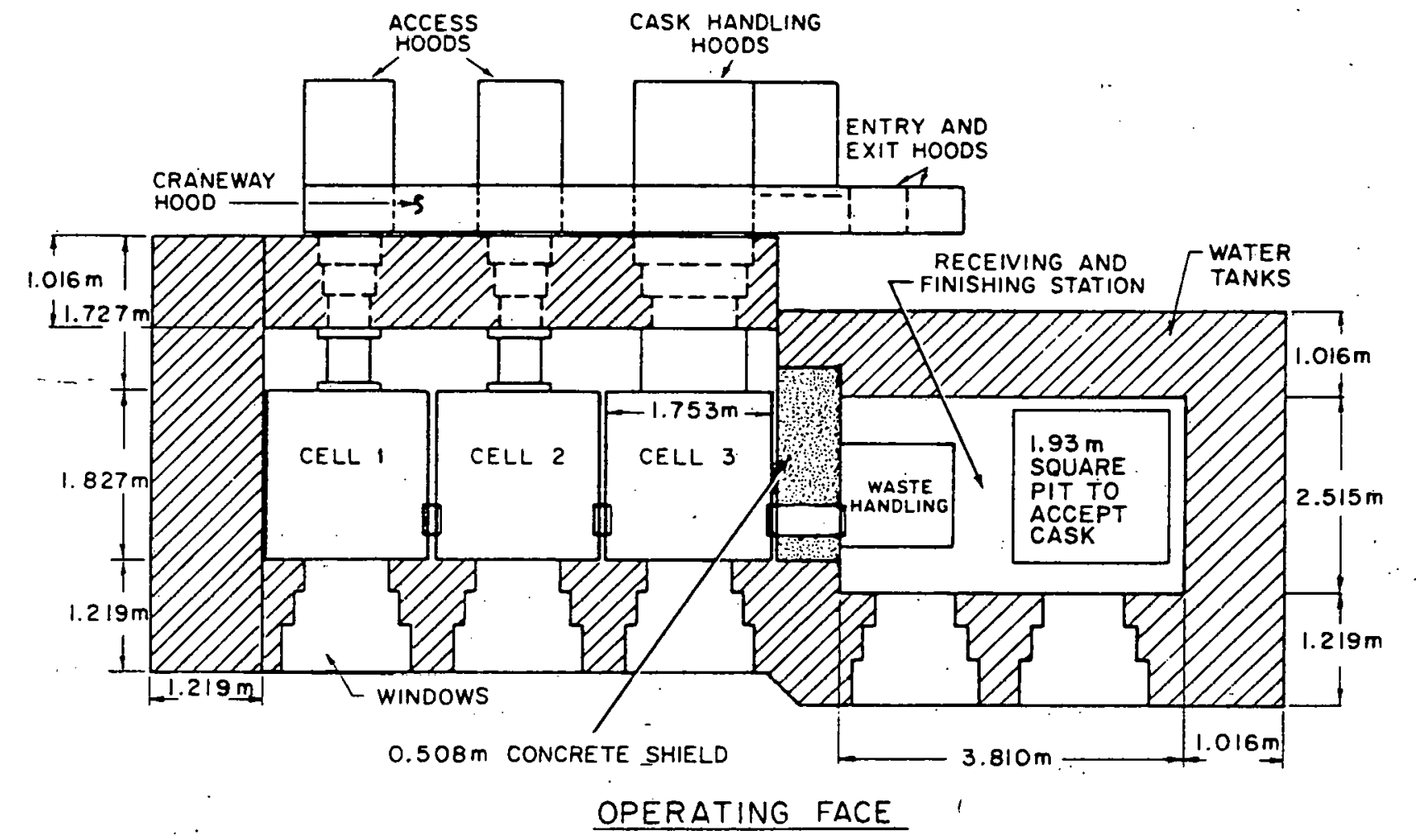

Fig. 9 Californium packaging facility 


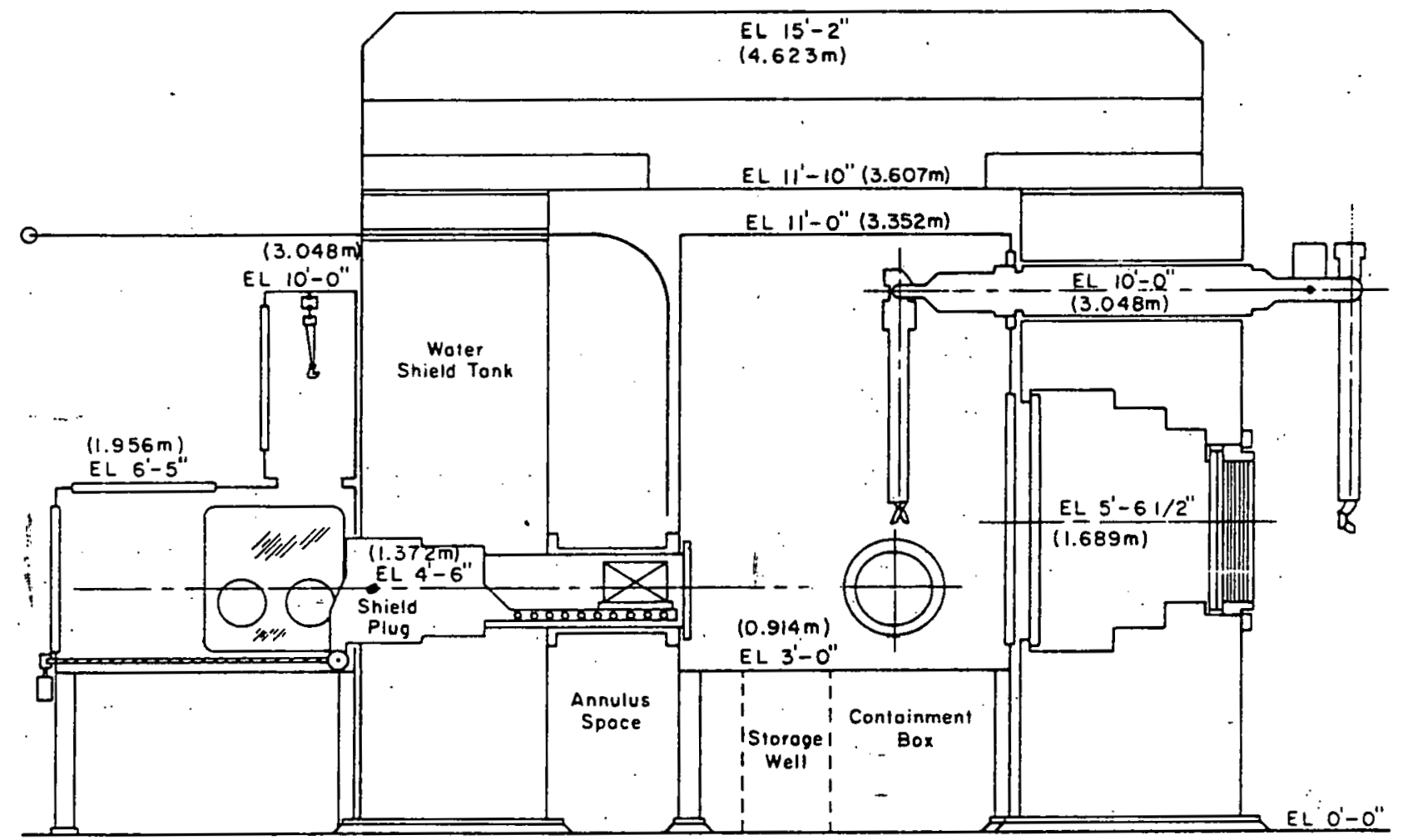

Fig. io Californium packaging section 


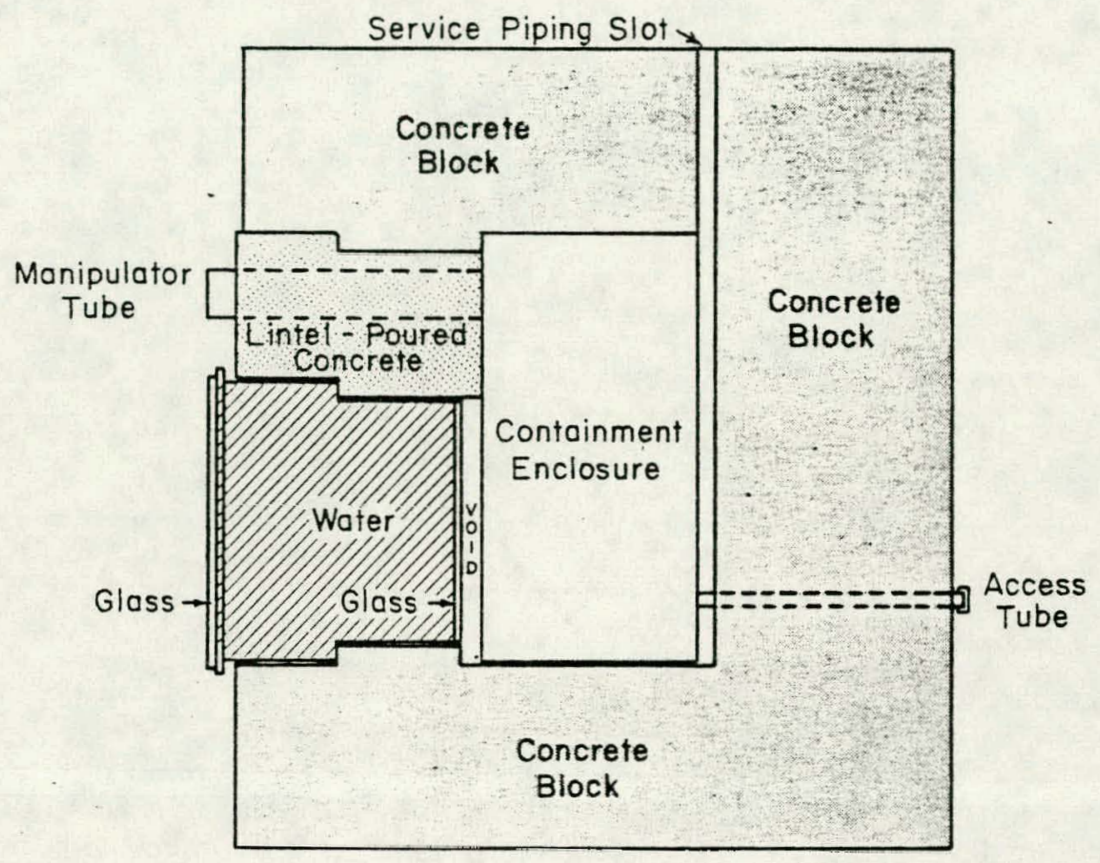

Fig. 11 Typical section - Californium Medical Source Facility 


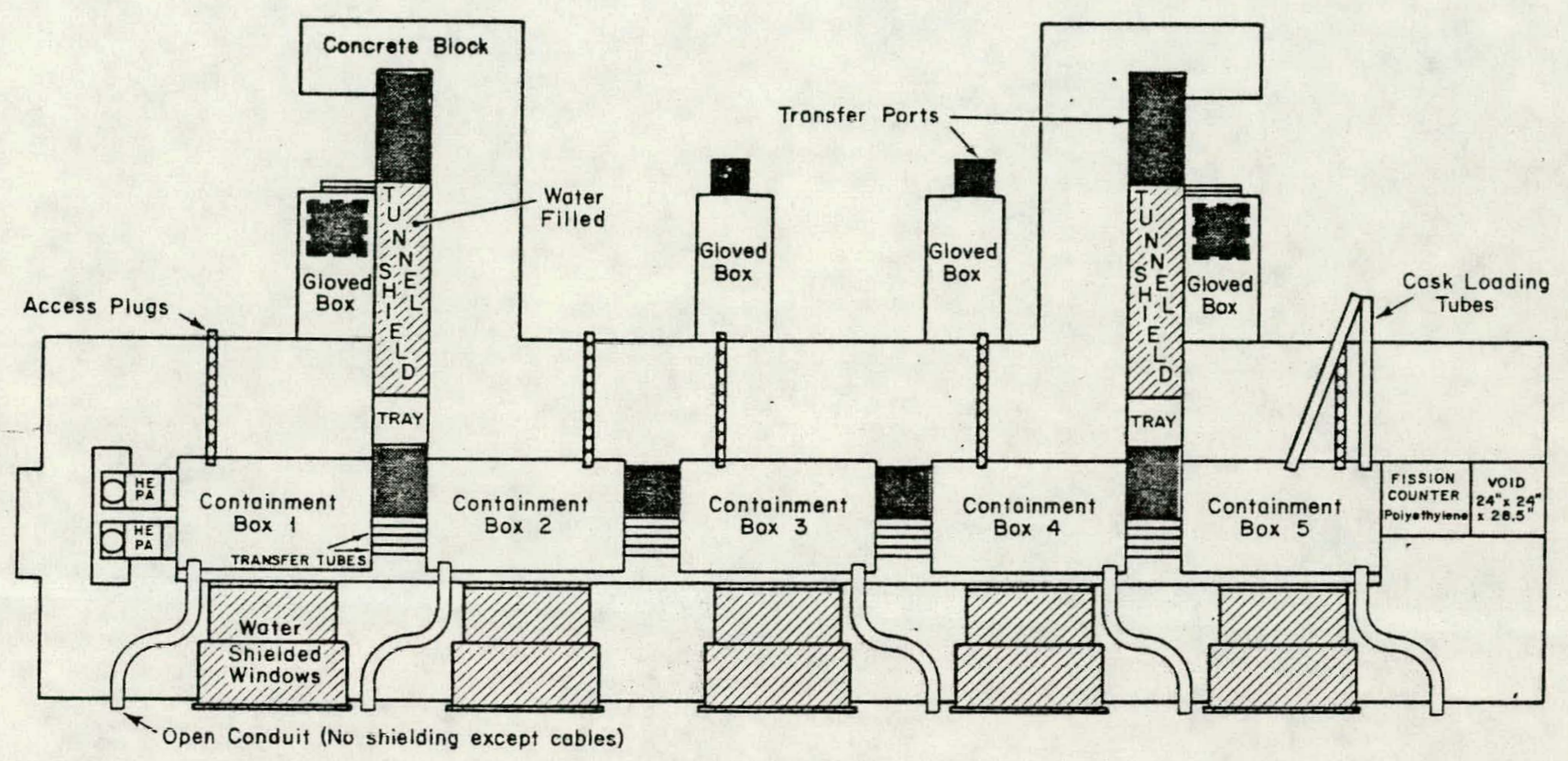

Fig. 12 Plan view - Californium Medical Source Facility 


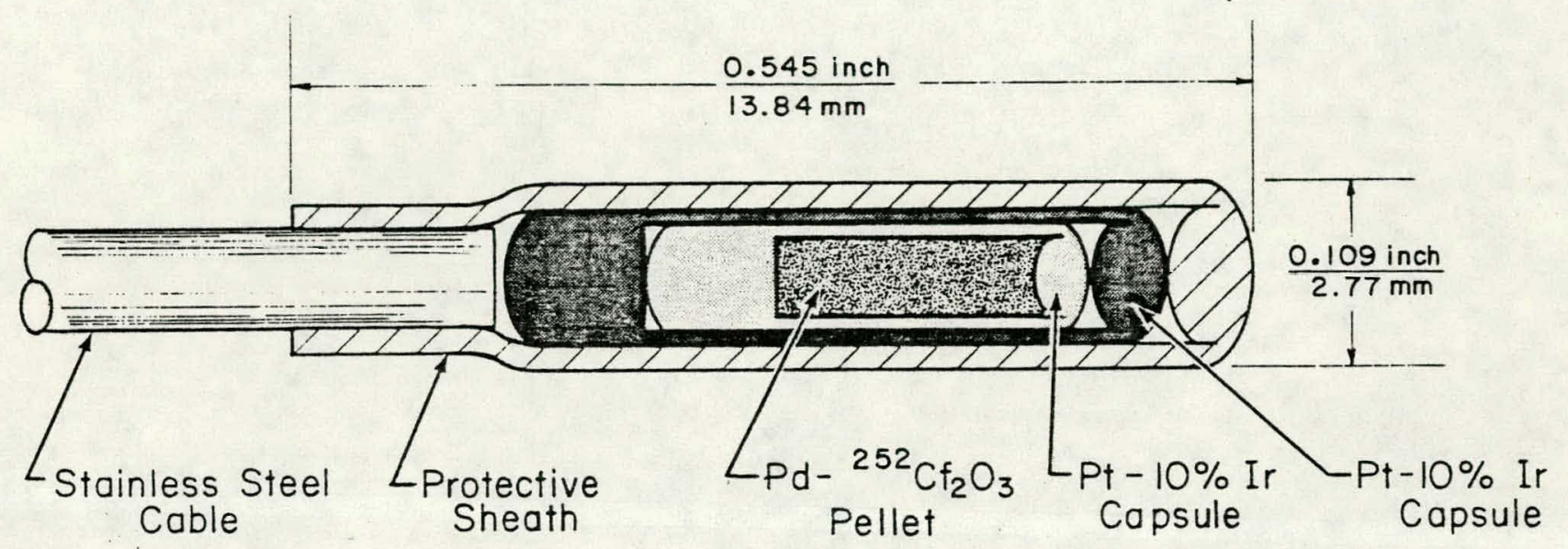

Fig. $13 \quad{ }^{252}$ Cf "Brachytron" source 

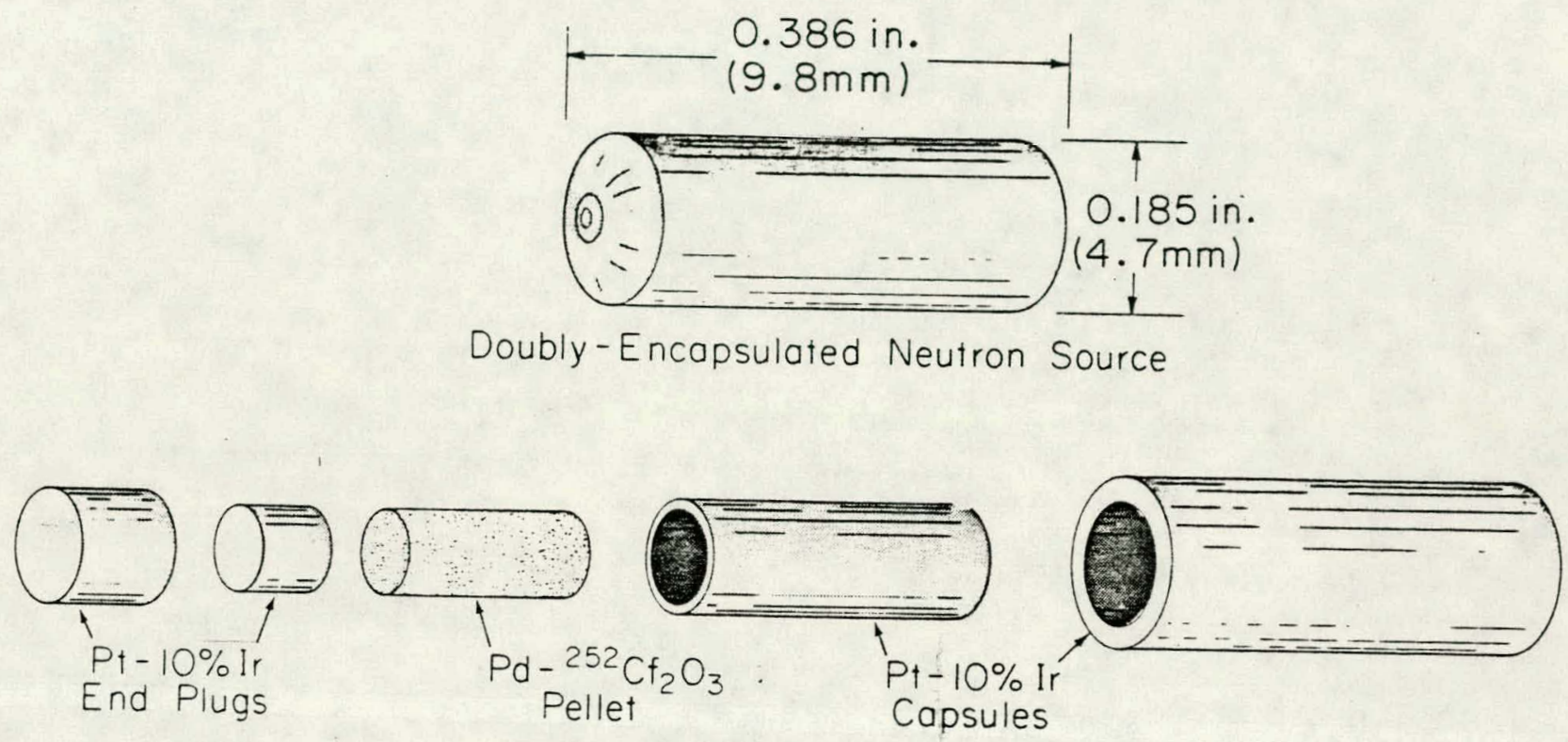

Fig. 14 Toshiba ${ }^{252} \mathrm{Cf}$ afterloading source 


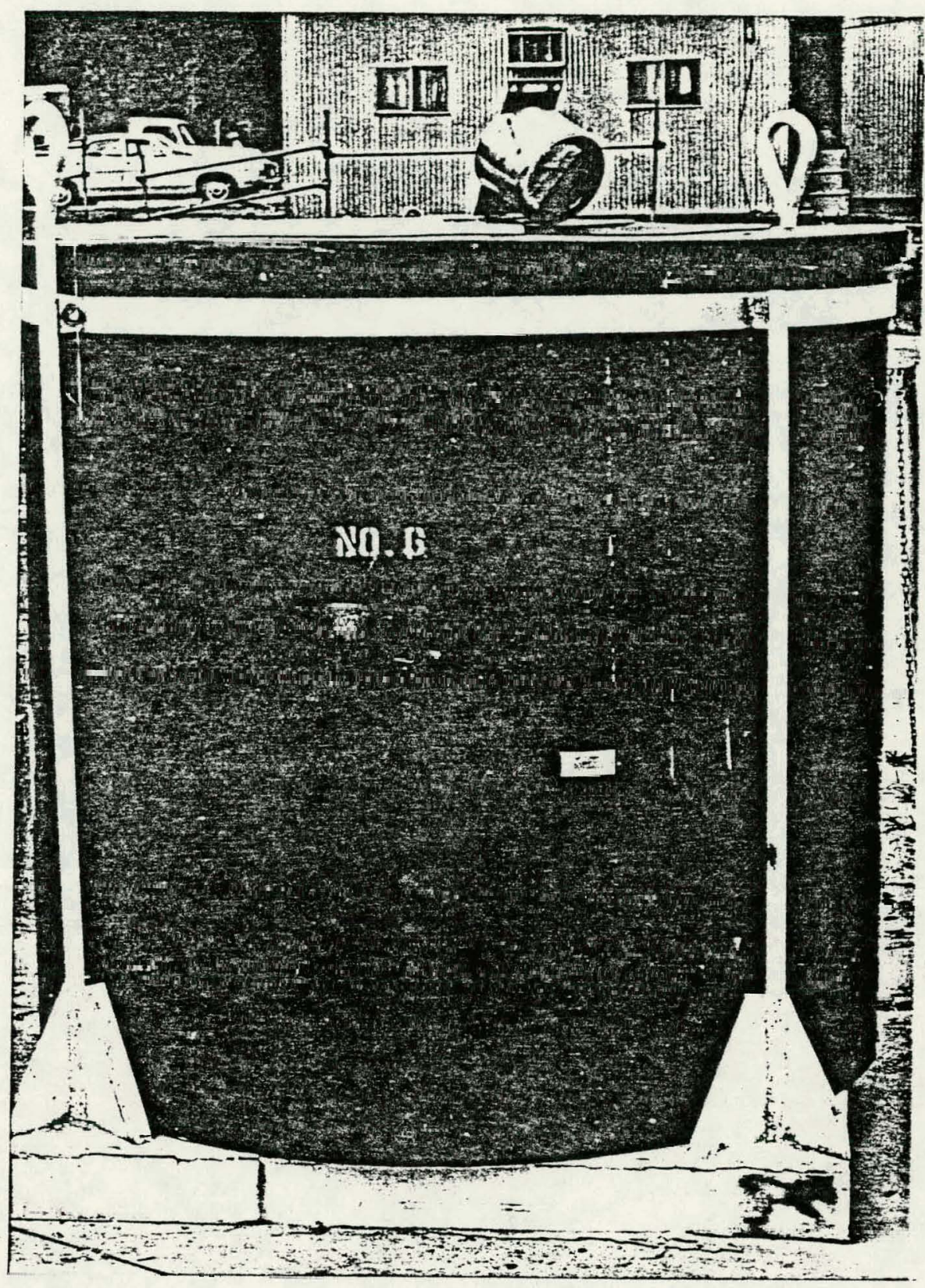

Fig. 15 WEP-Shielded ${ }^{252}$ Cf Storage 


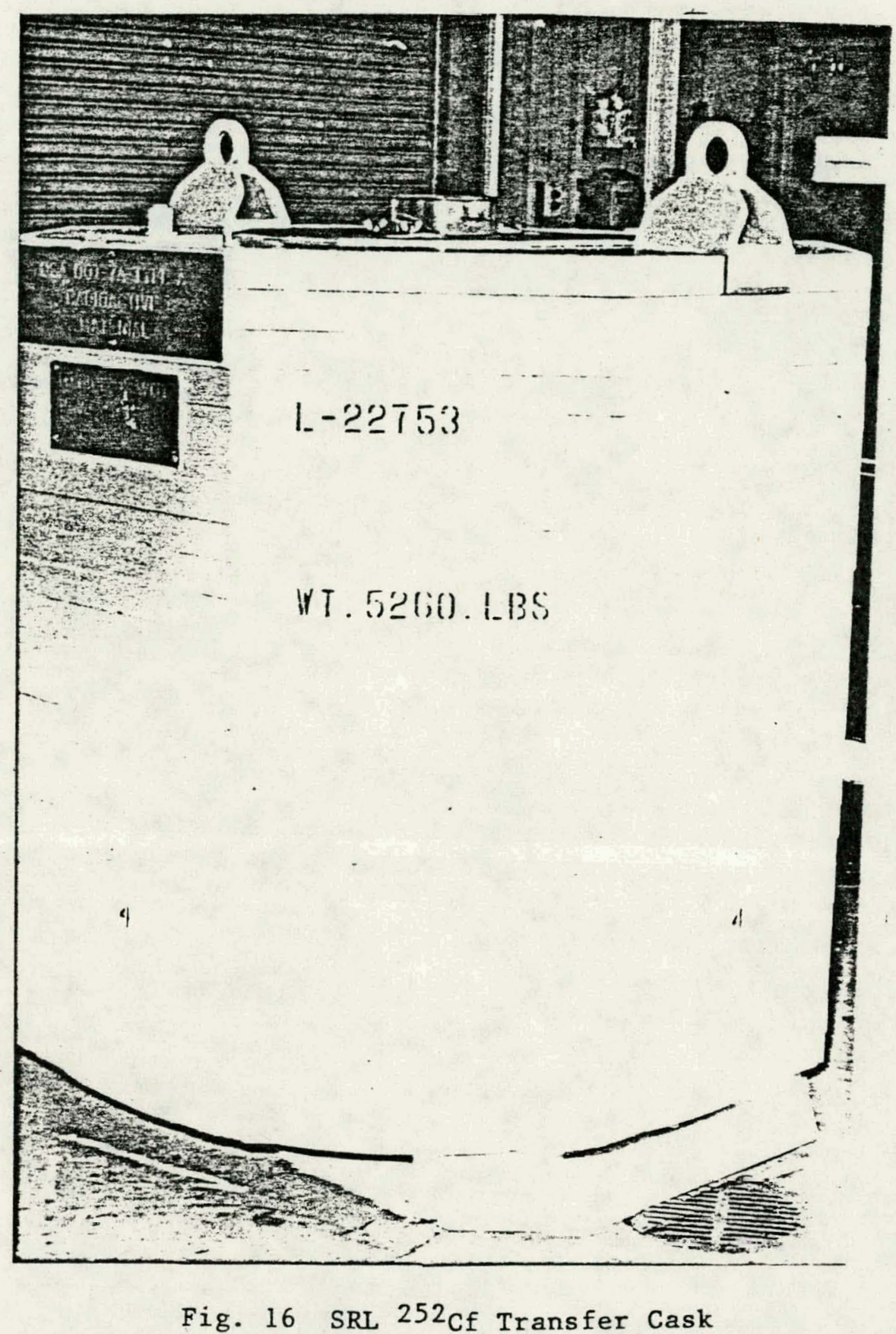




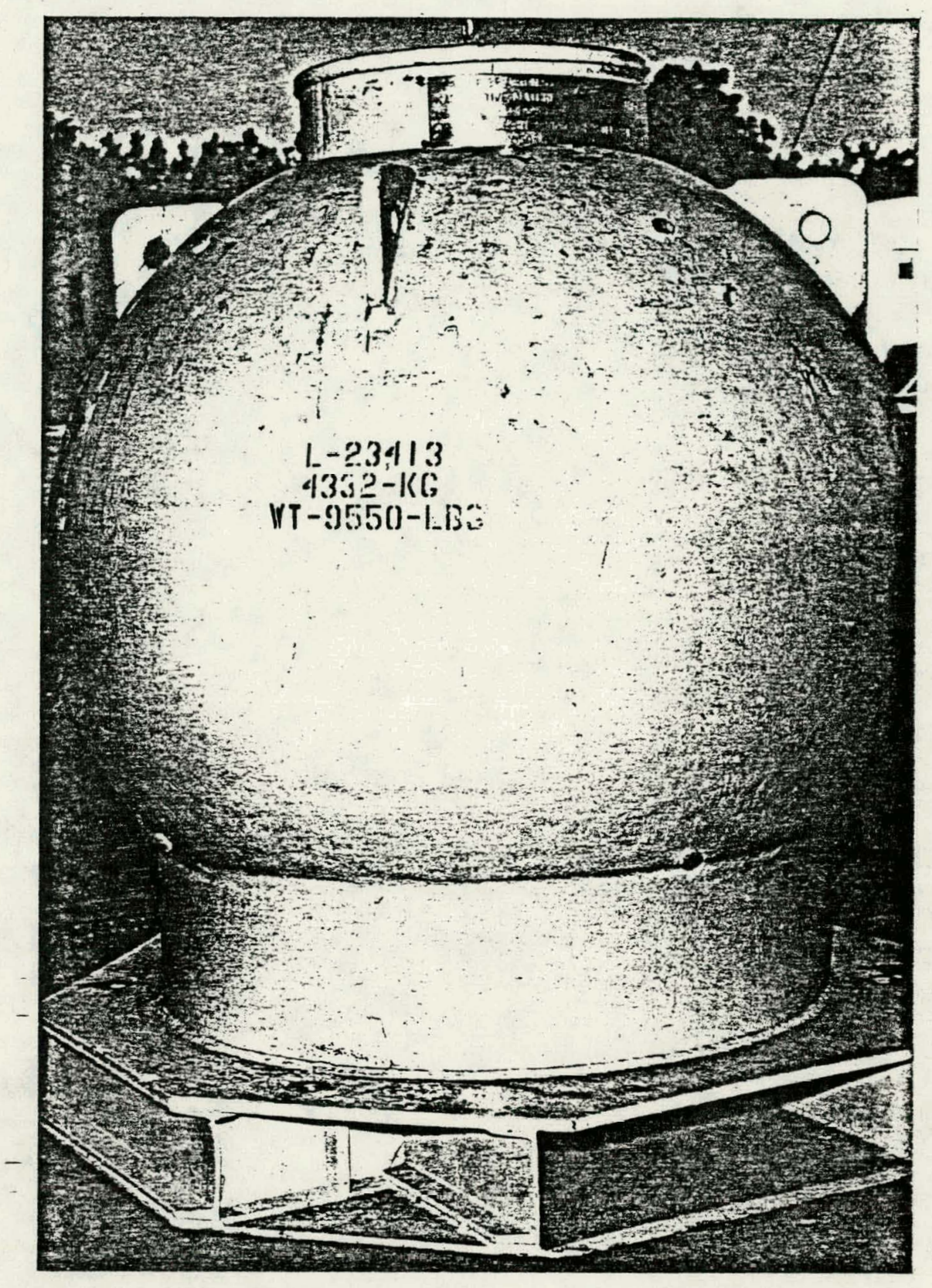

Fig. 17 SRL 4.5-Ton Californium Shipping Cask 